\title{
Experiences with Conservation Tillage Vegetables in Tennessee
}

Alvin D. Rutledge

ADDITIONAL INDEX WORDS. conservation tillage, minimum tillage, reduced tillage, strip tillage, vegetable crops

Summary. R esearch yields of conservation tillage (CT) snap beans (Phaseolusvulgaris $L_{\text {.) }}$ and sweet corn (Zea mays L. var. rugosa Bonaf.) have been less than those produced under conventional tillage. This has been due to soil conditions at planting, the cover crop used, weed control and a lack of proper design in equipment for CT. H owever, some growers have been successful with CT for sweet corn using hairy vetch (Vicia villosa Roth.) as the cover crop. $0 \mathrm{n}$ farm demonstrations of CT with cabbage (Brasica olerace L. C apitata G roup), pumpkins (C ucurbita pepo L.), tomatoes (Lycopersicon esculentum M ill.) and watermelons [Citrullus lanatus (Thunb) M atsum. \& N ak.] have been succesful and with good management it is commercially feasible under Tennessee conditions. Advantages include reduced soil erosion, cleaner products, more efficient application of crop protection chemicals, quicker planting after rainfall, lower energy costs and facilitation of harvest in wet weather. D isadvantages include reduced weed control, modifications of existing equipment, less uniformity in seed coverage and problems with transplanting, cover crop residue in mechanically harvested crops, possible delays in early harvest of fresh market crops due to delayed maturity and limited application of soil protective chemicals.

he time for conservation tillage (CT) of vegetable crops is fast approaching. Commercial vegetables contribute $\$ 80$ million annually to the Tennessee economy (A.D. Rutledge, unpublished). The rolling terrain in eastern and central Tennessee lacks the large areas of level land needed for crop production. Western Tennessee is more suited to large acreage row crops, many of which are already being produced with $\mathrm{CT}$ methods. $\mathrm{H}$ owever, vegetable acreage is more concentrated in central and eastern Tennessee. A high percentage of land in this area is subject to erosion, due to the slope and slow water penetration into the soil. Sloping land that is cropped intensively with conventional tillage methods and high value crops will not remain productive over an extended period of time due to soil loss from water erosion. If high value crops are to be produced on a portion of this land, it will require production with practices that stabilize the soil surface. Thus, the necessity for CT is increasing. In addition, much of the level land suited for crop production is gradually being converted to nonagricultural uses, such as subdivisions, highways, industrial sites and shopping centers.

Professor, Extension Plant and Soil Science, U niversity of T ennessee, Knoxville, Tennessee 37901-1071.

The cost of publishing this paper was defrayed in part by the payment of page charges. U nder postal regulations, this paper therefore must be hereby marked advertisement solely to indicate this fact. 
Existing growers have used conventional methods to grow high value crops for many years. They prefer to produce vegetable crops conventionally when there is weed competition, which may reduce both yield and quality. Therefore, any CT practice must reduce soil erosion, not inhibit yields and/ or quality or delay harvest of early planted crops. M aking decisionsconcerning the adoption of CT techniques can be partially addressed by considering the various management practices associated with such systems (Bradley and Tyler, 1996).

\section{Basic management decisions}

What aRe the positive aspects? Conservation tillage has been studied with several agronomic crops as well as some vegetables (Graves, 1996; H oward et al., 1996; Kelly, 1993; Kreuger et al., 1995; Morse, 1998; Mueller and $\mathrm{H}$ ayes, 1996; Rutledge, 1998; Straw et al., 1993). $\mathrm{N}$ ot all vegetables can be successfully grown under CT. H owever, when feasible practices exist to insure successful production, there are several advantages to $\mathrm{CT}$. O ne advantage is reduced soil loss into surface waters because of higher crop residue on the soil surface. U sing CT is a good way for growers to demonstrate that they are concerned about the environment and about protecting thenation'swater resources. C ropsthat can be satisfactorily produced can be harvested in cleaner condition (Rutledge, 1996). This improves fresh products and reduces cleaning costs to the packer, grower or processor. Residues on the soil surface from the cover crop enablegrowersto apply crop protection chemicals much more effectively when the need arises. With the residue cover, growers can get into the fields sooner after a rain or irrigation with reduced equipment slippage and without reduced soil erosion due to mechanical rutting of the land (M orse, 1998; Rutledge, 1997). Also, timely application of pesticides for disease and insect management following rain will reduce crop losses. With this practice, a higher product quality can be provided to the consumer with fewer losses to the grower. In addition, vegetables can either be seeded or transplanted veryquicklyfollowing arain. Planting when soil moisture is ideal is much easier and enables better soil contact with seed or transplants. This often results in higher and more uniform plant populations. Lower energy costs aid in reducing production costs but does not increase costs to the consumer. $\mathrm{Fi}$ nally, cover crop residue improves water conservation due to more rapid infiltration, and it lowers soil surface evaporation (Tyler et al., 1994). This results in reduced irrigation applications and may even contribute to less use of crop protection chemicals, due to less wash off of the foliage.
What are the negative aspects? O ne of the major drawbacksisa lack of effective herbicides to keep the weed competition to a minimum. Weed control has to be accomplished with a variety of practices utilizing cover crop residues on the soil surface, herbicides when they are both available and effective, and perhaps even do some hand weeding.

Equipment modifications are necessary to plant vegetables under CT conditions because manufactured equipment is not al ways suitable to satisfactorily accomplish planting operations. Seeders arelikely to requiremodifications in the type of coulter used, the opening shoe, the seed dropping mechanism, the seed covering devices and press wheels. $M$ any of these modifications are now being incorporated into seeders by manufacturers. T ransplanters are al so likely to require similar modifications. Transplants are usually grown in containers or in cell trays, and as a result, the weight and volume of the root ball may not allow the plant-holding mechanism to correctly position the plant in the soil. In addition, the closing wheels may need to be modified with additional weights to enhance planter penetration into thesoil. Precisedepth of coverage is important for all vegetable seeds. U niformity of emergence is critical to uniformity of harvest, because of the short time frame for harvest. $\mathrm{H}$ arvesting cannot be delayed until all the crop is ready as is common with grains. Vegetables are harvested based on freshness and size, and any practice which does not provide maximum yields, uniform size and high quality reduces product desirability and grower income.

Conservation tillage of vegetable crops may require that land be prepared in the autumn before spring planting to effectively insure the positioning of nonleachable fertilizer materials in the root zone. This is especially true if the $\mathrm{pH}$ is improper, or the field is low in phosphate and potassium. Conventional preparation allows fertilizer application at or near the time of planting. Preparing the field in the autumn by working in lime and nonleachable fertilizer, and seeding a heavy rate of the cover crop, increases the potential for good yields and quality of the cash crop. In T ennessee, most successful vegetable production using CT has used seeded cover crops rather than established fescue (Festuca L.) sod at the time of planting. If plans are not made to establish a thick cover crop residue, and planting occurs in an old sod field in the spring, crop disaster is very likely due to the germination and growth of weeds. If this condition is present or expected, growersmust plan to grow a crop that has an effective herbicide program available.

If harvesting an early vegetable crop, a thick cover crop residue may keep the soil 
temperature cooler a few days longer than conventional tillagesystems. This could result in delayed emergence of seeds or delayed growth of transplants, in turn decreasing early market sales. $\mathrm{H}$ owever, developing raised beds in thefall for spring planting may shorten the delay. When fresh market prices of commodities such as to matoes or cabbage can decline as much as a $\$ 1.00 /$ box per day, growers favor systems that increase or maintain early maturity. But, for crops grown later in the season, CT may prove to be a very good system for adequate quality and yields, better water conservation and cooler soil temperatures.

Cover crop residue can be a significant disadvantage to low-growing, mechanically harvested crops such as snap beans. Bean pods are often set low enough on the plant that the harvesters pick up the cover crop residue as well as the pods and deliversit to the bulk harvesting container (Rutledge, 1996). L odging of thesnap bean plants also greatly increases the amount of residue going into the harvesting container. Such residue has to be removed before the product is packaged. This extra cleaning usually results in increased costs that are passed back to the grower. Thus, CT practices with such crops require cover crops that have a growth habit which prevents the residue from being picked up by the harvesting equipment.

With $\mathrm{CT}$, the selection of soilapplied chemicals is limited for vegetables. Certain soil fungicides or insecticides that cannot be concentrated in the root zone without crop injury require further modification of planters. The application of fumigants is very difficult if not impossible. These factors combined with increased cover crop residue may contribute to increased root disease and insect problems that lessen the desirability of CT for vegetable production.

Most suitable situations. O ne of the more important factors of CT is the selection of herbicides available for weed control, in the event that a thick residue of the cover crop is unavailable for weed suppression. Weeds create undesirableconditionsfor crop growth and production when they are not controlled. Vegetable crops that have effective herbicides available for use with CT practices include tomatoes, snap beans, sweet corn, southern peas [Vigna unguiculata (L.) Walp.], and cole crops (Brassica L.). M any of the other vegetable crops do not have a broad selection of effective herbicides for use either under conventional or CT practices. Thelatter group requires athick layer of cover crop residue to be in place before the intended planting date. It is also important to control weeds, especially perennials, in other crops in the rotation, and to avoid fields with high populations of weeds.

Well-drained soils contributeto a favorableCT situation. A well-drained soil is dry and warm quickly, thus enabling growers to plant and harvest earlier and take advantage of higher prices. A well-drained soil also reduces wet spots during the growing season, lessens the incidence of root disease problems, and improves both plant stands and total season growth.

Good soil moisture at the time of seeding or transplanting is a great advantage, especiallyif the soil ismedium to finetextured. If moisture is present, the coulters and/ or furrow openers will provide a uniform furrow that allows adequate covering of the seed or compression around the root ball of transplanted crops. I f thesoil isdry and hard, a uniform depth of penetration of the coulters and disc openers is very difficult to achieve. I n such cases, plant survival islow. Very dry soils may need to be irrigated before seeding or transplanting.

Growing crops that have large seed or vigorous transplants is an advantage. Large seeded crops have greater vigor, are less sensitive to coverage techniques and establish more easily than small seeded vegetables. Vigorous transplants also establish more quickly and are not as subject to damage during the transplanting operation as less vigorous transplants.

Crops that do not need soil treatments for diseases, insects or nemato des are a real advantage, but that is a rarity in vegetable production. Almost all vegetable crops that are grown in Tennessee have some susceptibility to one or more of the soilborne disease, insect or nematode problems. As a result, equipment modification will need to include arrangements for the application of the necessary chemical control to reduce problems from these soilborne pests. Where in-furrow application or seed treatment is effective, this will be less of a problem.

A thick layer of the cover crop residue is both conducive to good weed control and to reducing soil moisture loss during the growing season (M orse, 1998). It may be a disadvantage to planting however, depending on the crop being grown, the nature of the cover crop residue and the equipment modificationsavailable.

Preplant soll preparation pracTICES. It is highly advisable that the following preplant soil and field management practices be done in the fall before spring planting (Rutledge, 1998). If the field has not been under tillage practices for a few years, the soil $\mathrm{pH}$, residual fertility and lime level need to be checked.

In addition, there may be problems with perennial weeds that cannot be managed with the selection of herbicides available for the desired crop during the growing season. Reducing or eliminating perennial weed problems may require one or two applications of glyphosate (Roundup) the summer before seeding of the cover crop or vegetable crop production. Finally, assuring a good stand of the cover crop requires seeding in the fall, before spring planting of the vegetable crop. A thick stand of the cover crop available for burn-down near the time of planting resultsin moretotal mulch, better water conservation and subsequently more effective weed control during the growing season. Failure to obtain a good stand of the cover crop results in a very thin ground cover, increased weed problems and unclean fruit due to adherence of soil particles.

Preparation techniques that have been successfully used in Tennessee include applying the necessary fertilizer nutrients, working them into the root zone and early fall seeding with either hairy vetch or a thick stand of a small grain such as rye (Secale cereale L.) or wheat (Triticum aestivum L.) (Straw et al., 1995). H airy vetch should be planted with a small grain on highly erodible soils. If seeding is not done early enough to enable good fall growth, hairy vetch will not provide adequate cover. In Tennessee, where no preplant preparation was done, serious vegetable production problems have resulted. O ne of these problems has been the necessity to apply directed sprays for weed control during the growing season (when effective herbicides are labeled for use). Another problem can be soil compaction in fields that have been used to graze cattle for long periods of time. To 
accomplish transplanting in these situations, rows may need to be subsoiled, and the field watered by rainfall or irrigation before successful transplanting can occur. Old pasture fields may also have nutrient imbalances such as low pH , phosphateand potassium levels. Such fields should be prepared before autumn planting. To prepare for seeding, the nonleachable nutrients can be applied and incorporated into the root zone.

Managing the cover crop. The cover crop can be killed with paraquat (G ramoxoneE xtra) or glyphosate, depending upon the crop and the stage of growth. Paraquat is effective in killing either small grain crops or vetch, when they are used for early plantings. $\mathrm{H}$ airy vetch, however, may require morethan one application of paraquat to provide a complete kill. At certain growth stages, glyphosatemay bemore effective than paraquat on wheat. $\mathrm{H}$ owever, if the situation demands an early spring application to an immaturecover crop in preparation for transplanting a cool season vegetable crop, paraquat will produce a quicker burndown.

A tall growing cover crop can be mowed or chopped, and allowed to lie in place, or it can be killed with glyphosateor paraquat and rolled with a heavy roller to break it over and force it to lie on the soil surface. This technique works well with tall growing cover crops with rigid stems. Finer stemmed plants, such as an immature small grain, can either be killed chemically followed by transplanting without mowing, or they can also be mowed and allowed to lie on the soil surface. The vegetable crop is then seeded or transplanted through themulch. I the cover crop ismowed, regrowth may be a problem unless there is a directed spray available for use after emergence or transplanting of the vegetable crop (M orse, 1998; T yler et al., 1994).

A rigid stemmed cover crop such as foxtail millet [Setaria italica (L.) Beauvois)] will require heavy cutting coulters and opening discs to enable a good furrow opening regardless of the vegetable crop being produced. With fined stemmed cover crop plants, a rolling coulter and double disc openers usually provides good seed to soil or root to soil contact.

DiReCt SEed EQUIPMENT MOdIfICATIONS. The research team of Charles M ullins, Allen Straw, D ave C offey and
J im Wills at the $U$ niversity of T ennessee have been evaluating $\mathrm{CT}$ production of snap beans and have made several equipment modifications. They have been using a Kinze model 820 planter (Kinze $M$ anufacturing, Williamsburg, I owa) with aJ ohn D eere $M$ axE merge planter ( $D$ eere $\&$ Co., M oline, III.). O ne of themodifications is the replacement of a 1.5-inch (3.8$\mathrm{cm})$ fluted coulter with a 0.75 -inch $(1.9-\mathrm{cm})$ bubble coulter. When there isgood moisture in the soil, thebubble coulter provides a better furrow for uniform planting depth. $\mathrm{H}$ owever, if the soil is dry, there is not much differencebetween thefluted and thebubble coulter in plant survival and growth. Another modification is the replacement of rubber press wheelswith metal wheels. The rubber wheel is too wide to provide adequate pressure over the seed after it is dropped into the furrow. The metal wheel is narrower and increases the pressure directly over the seed, which increases the seed to soil contact, resulting in both increased emergence and uniformity of emergence. A final modification is the addition of tension adjusters to the press wheels, which increases control of soil compaction over the seed.

Transplanter modifications. Jim Wills, U niversity of Tennessee, agricultural engineer, made several modifications to a M echanical 1000 transplanter (Mechanical Transplanter, $\mathrm{H}$ olland, $\mathrm{M}$ ich.). The changesinclude the addition of a 14 -inch $(35.6-\mathrm{cm})$, eight wave fluted coulter to improve furrow openings for the purpose of transplanting plants with a 1.5- to 2inch (4- to 5-cm) root ball. In addition, opposed doubledisc furrow openers are mounted behind the front rubber press wheel just ahead of the opening shoes. Another modification is removing the curved surface of the stock press wheel and cutting thestock wheel to a 2-inch $(5-\mathrm{cm})$ width. To the outer surface of the stock wheel, a $0.75 \times$
0.75 -inch $(1.9-\mathrm{cm})$ metal ring iswel ded to the inner edge and outer circumference of thestock wheel. Thisisdoneto improve soil compaction around the root ball during transplanting. Weights are added to the transplanter at two locations. The potential to add up to $400 \mathrm{lb}(181 \mathrm{~kg})$ over the front coulter and up to $300 \mathrm{lb}(136 \mathrm{~kg})$ behind the press wheel is provided. All of these modifications make the transplanter useful for small farm and demonstration plantings. The sametype of modifications can be made to a larger, multiple-row, commercial unit; however, it will also be necessary to strengthen the frame to support heavier equipment.

Problems with transplants. When using the modified M echanical 1000 transplanter, someproblemswere encountered with container-grown transplants as follows: 1) if the soil is too wet, theplanting furrow will harden excessively once it begins to dry, resulting in root constriction and reduction in the rate of plant growth; 2) compact and fine textured soils do not enable a deep enough furrow opening to completely cover the root ball, which can reduce plant stand and vigor, especially in fields having a variation in soil type. 3) Since the transplanter was designed to handle bare-root transplants in conventional tillage systems, the weight of the root ball tended to cause the plant to fall out of the holding fingers unless plants were held manually until the holding fingers enclosed around them. 4) Variation in soil conditions may affect the ability of the stock wheel to firmly compress the soil around the root ball.

\section{Results}

\section{Research}

Tables 1 and 2 provide a brief summary of snap bean and sweet corn research yieldswith $\mathrm{CT}$ practicesusing the Kinze planter at the Plateau Experiment Station in Crossville, Tenn.

\section{Table 1. Effect of conservation tillage on snap bean yields at Plateau Experi- ment Station, Crossville, Tenn.}

\begin{tabular}{lccc}
\hline & \multicolumn{3}{c}{ Yield (Ib/acre) $^{\mathbf{z}}$} \\
\cline { 2 - 4 } Year & N o-till & Conventional till & Strip till \\
\hline 1993 & 2,604 & 3,742 & --- \\
1996 & 4,311 & 9,791 & --- \\
1997 & 1,746 & 4,491 & 2,125
\end{tabular}

z $1.0 \mathrm{lb} /$ acre $=1.12 \mathrm{~kg} \cdot \mathrm{ha}^{-1}$

yStrip-till refers to tilling a 12 - to 18 -inch $(30-$ to $46-\mathrm{cm})$ band in the row area of a conservation tillage field before planting.

Hortlechnology • July-September 1999 9(3) 
T able 2. Plant population and yield of 'Silver Q ueen' sweet corn grown under different conservation tillage practices.

\begin{tabular}{lcc}
\hline $\begin{array}{l}\text { Tillage } \\
\text { practice }\end{array}$ & $\begin{array}{c}\text { Plant population } \\
\text { (plants/acre) }^{\mathbf{z}}\end{array}$ & $\begin{array}{c}\text { Yield } \\
\text { (dozen/acre) }^{\mathbf{y}}\end{array}$ \\
\hline Conventional $_{\text {Strip till }}^{\mathrm{x}}$ & 22,942 & 1,475 \\
N o till & 21,043 & 1,256 \\
\hline
\end{tabular}

${ }^{\mathrm{z}} 1$ plant/ acre $=2.5$ plants/ ha.

y1 dozen/ acre $=29.7$ ears/ ha.

xStrip-till refers to tilling a 12 - to 18 -inch $(30-$ to $46-\mathrm{cm})$ band in the row area of a conservation tillage field before planting.

In general, higher yields of both snap beans and sweet corn have resulted from conventionally tilled plots. The reasons for this are improved tilth at planting and reduced competition from weeds during some years of the trial. As mentioned earlier, when sufficient moisture is not present to enable good planter penetration, uniform seed coverage does not occur in CT plots. This resultsin poor germination and subsequent low plant populations, which equates to lower total yields. Because of such conditions, modifications in equipment are being evaluated as to whether or not growers can effectively grow a crop under less than optimum soil tilth. M any growers cannot wait for ideal weather conditions before planting because this delays maturity and they lose the market advantage.

\section{On-farm demonstrations}

Pumpkins. A no-till corn grower tried someno-till pumpkinsusing hairy vetch as the cover crop. To accomplish the CT techniques, the farmer prepared a 4-acre (1.6-ha) tract of land in
Fall 1995 and seeded hairy vetch. In June 1996, the vetch was killed with paraquat. A second application was made $10 \mathrm{~d}$ later to completely kill any remaining vetch. In mid-J une, 'ProGold 510' pumpkin was hand seeded on a $10 \times 10$-ft $(3-\mathrm{m})$ check. M etal coulters were spaced $10 \mathrm{ft}$ apart on a tool bar and were run perpendicular to each other across the field to slice through the vetch residue. Where they intersected, three seeds per hill were hand planted. (It can be noted, however, growers are now using planters to plant pumpkins at closer in-row spacings than those used in this demonstration.)

D uring the growing season, there was some carpetweed ( $M$ ollugo verticillata L.) and other prostrategrowing broadleaf weeds in addition to a few small clumps of johnsongrass [Sorghum halepense (L.) Pers.] in the field. Therewereno herbicidesused to control broadleaf weeds in this trial because there are no labeled herbicides that permit directed spray appli-

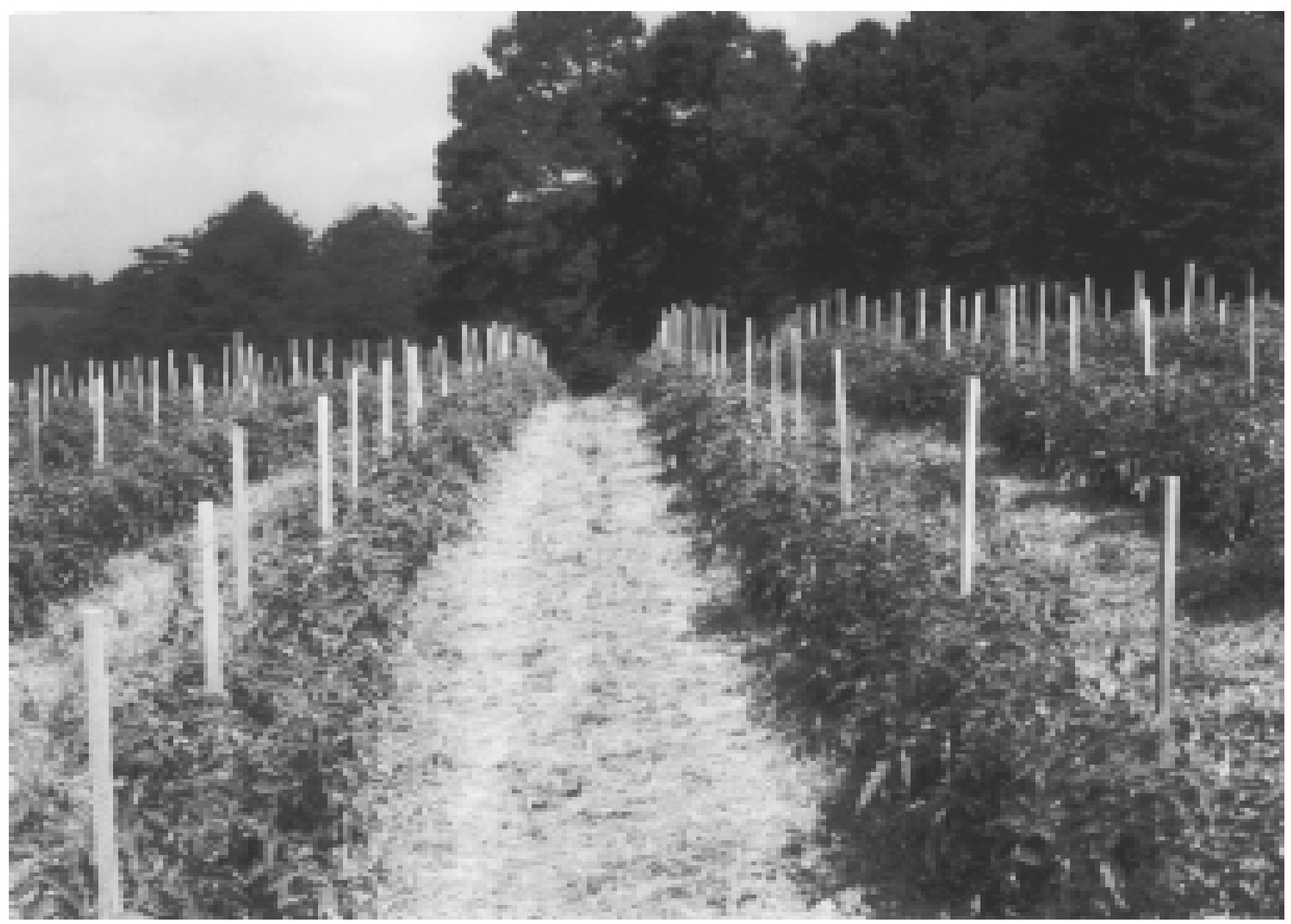

Fig. 1. Minimum-till tomato field in Cocke C ounty, Tenn. Plants were transplanted into fescue sod and weeds were controlled by directed sprays of metribuzin. 
cations. The growth of johnsongrass was kept to a minimum by over-thetop applications of sethoxydim (Poast) herbicide. The vetch residue present on the soil surface at the time of planting held quite well until the pumpkin vinesessentially covered theentirefield. This helped to keep the weed competition to a low level. Some fungicide applications for downy mildew [P seudoper on ospora cubensis(Berk. and Curt.) Rostw.] and powdery mildew [Sphaeotheca fuliginea (Schlecht.) Poll.] control were made throughout the season.

At harvest, the pumpkins had a veryglossy, brilliant yellow-gold color. They were full sizeand were clean with a low incidence of discoloration from lying on the vetch throughout the growing season. From the 4-acre(1.6ha) block, 7,200 pumpkins were harvested.

In the sameyear, the same grower also successfully produced a 5-acre (2ha) block of 'Silver Q ueen' sweet corn using aJ ohn D eereM axE mergeplanter to seed through the vetch residue.

Tomatoes. Conservation tillage of tomatoes has also been tested by individual farmers on their own farms. D uring the summer of 1994, a commercial tomato grower in Cocke County, T ennessee planted 1 acre $(0.4$ ha) of late tomatoes in an established fescue sod (Fig. 1). The site had been in pasture for several years, and the soil was extremely compacted. The $\mathrm{pH}$, phosphate and potash all tested low. $\mathrm{No}$ attempt was made to incorporate lime, P or K into the soil beforetomato transplanting. N itrogen was applied as a band to the soil surface as needed during the growing season.

In early J une, glyphosphate herbicide was applied to thefescuesod. In June, the rows were opened with a subsoiler to improve both coulter and planter shoe penetration into the soil as well as to facilitate the driving of stakes for the trellis system. Following a rain on 22 J une, transplanting was attempted on 23 J une using the modified M echanical 1000 transplanter described previously. The soil was quite wet in the subsoiled area and the transplanter did not operate efficiently. The farmer had grown his own plants in containers with 1.25- and 1.5-inchdiameter $(3.2-$ and $3.8-\mathrm{cm}$ ) root balls. Themotion of thetransplanter through the wet soil created conditions that reduced consistent release of plants from the transplanter fingers. It was necessary to delay transplanting by $1 \mathrm{~d}$ to allow some soil drying. When this was doneand theweightswerealtered, transplanting worked almost as well as in a conventional tillage system. H owever, field modifications of furrow openers had to be made to accommodate container-grown plants, and personnel who inserted transplants into the fingers of the transplanter had to learn the correct method of placing transplants.

During the growing season, directed sprays of metribuzin (Sencor) was used to control emerging weeds between the rows. The thin fescue sod was not highly efficient in reducing weed germination and growth, but the metribuzin and fescue residue combined kept weeds under control and enabled good movement of spraying equipment for timely application of pesticide after a rain. $D$ ue to the low fertility level of the soil, certain fertilizer deficien cy symptomswere becoming visible as the crop matured, but severe deficiency symptoms never developed during the growth period.

Generally, the trial was a success. The grower harvested late tomatoes and sold them locally on a retail market. $H$ is gross sales totaled $\$ 7,200$ for the crop. H owever, in the future, better planning of cultural practices will be necessary to bring such fields to the required state of fertility and to establish a more effective cover crop before planting of tomatoes.

Cabbage. In M arch 1994, a 90acre (36-ha) conventional-tillage cabbage grower wanted to evaluate $\mathrm{CT}$ production on his own farm on rolling terrain. A trial field was planted with wheat as a cover crop in the fall of 1993, along with the incorporation of both phosphate and potassium. This trial was planted before the modifications in the Mechanical 1000 transplanter discussed earlier. Thus, the demonstration was a strip-till evaluation in combination with availableherbicides for weed control.
To prepare the plot, paraquat was applied to the wheat cover crop on 23 $\mathrm{M}$ arch 1994. On $25 \mathrm{M}$ arch, fertilizer was broadcast over the plot and a strip till unit set on 30 -inch $(76-\mathrm{cm})$ centers was used to prepare the row for transplanting. The strip-till system was combined with labeled herbicides to evaluate weed control and yields of 'Gourmet' cabbage. There were four herbicide treatments used in the evaluation: 1) conventional tillage; 2 ) napropamide (D evrinol 50W) at $4 \mathrm{lb} / \mathrm{acre}\left(9.9 \mathrm{~kg} \cdot \mathrm{ha}^{-1}\right)$ incorporated preplant plusoxyfluorfen (Goal $2 X \mathrm{~L}$ ) at $2 \mathrm{pt} /$ acre $\left(2.6 \mathrm{~L} \cdot \mathrm{ha}^{-1}\right)$ applied to the surfacejust beforetransplanting; 3) pyridate (Lentagran 45WSB) at $2 \mathrm{lb} /$ acre $\left(2.9 \mathrm{~kg} \cdot \mathrm{ha}^{-1}\right)$ applied over thetop for broadleaf weed control $\approx 45 \mathrm{~d}$ before harvest; and 4) a weedy check. Three randomly selected 20 -ft $(6.1-\mathrm{m})$ row lengths were harvested once on 15 J une, when heads in the conventional tillagetreatment averaged $3 \mathrm{lb}(1.36 \mathrm{~kg})$ each. Weed control ratings weremade on the day of harvest. Weed control percentages and head weights are provided in Table 3.

Weed control in the conventional treatment wasquitegood because cultivation was used. Once the napropamide plus oxyfluorfen treatment was applied, there were no further weed control efforts because acceptable control was achieved with this treatment ( $T$ able 3 ). The pyridate treatment suppressed weed growth for a period of time, but by harvest time, weeds were becoming quite vigorous and competitive. Weed growth did not seem to inhibit hand harvest, but mechanical harvesting for processing purposes would have been impeded by the significant amounts of weed residue. $\mathrm{H}$ ead weight decreased with decreasing weed control. I t isfelt that the head size in napropamide plus oxyfluorfen and pyridate treatments would have reached the desired size with better weed control efforts or more time. Reduced head size at the time of harvest indicates that when cabbage competes with weeds, harvest

T able 3. Weed control evaluation in cabbage conservation tillage plots.

\begin{tabular}{lccc}
\hline Treatment & R ate/acre & $\begin{array}{c}\text { Weed control } \\
(\%)\end{array}$ & $\begin{array}{c}\text { Avg head wt } \\
(\mathbf{l b} / \mathbf{h e a d})^{\mathbf{z}}\end{array}$ \\
\hline Conventional till & --- & 98 & 2.76 \\
Napropamide + oxyfluorfen & $4 \mathrm{lb}+2 \mathrm{pt}$ & 85 & 2.29 \\
Pyridate & $2 \mathrm{lb}$ & 65 & 2.20 \\
Weedy check & --- & 0 & 1.81 \\
\hline
\end{tabular}

$\mathrm{z} 1.0 \mathrm{lb}=0.45 \mathrm{~kg}$. 
T able 4. Status of vegetable crop conservation tillage in T ennessee.

\begin{tabular}{lllll}
\hline C rop & $\begin{array}{l}\text { G rower } \\
\text { trials }\end{array}$ & Results & $\begin{array}{l}\text { H as it } \\
\text { increased? }\end{array}$ & Yield \\
\hline Tomato & Yes & Good & No, but has interest & Satisfactory \\
Cabbage & Yes & Good & Yes & Slightly less than the conventional \\
Snap bean & No & Varied & No & Varied \\
Sweet corn & Yes & Varied & Slightly & Varied \\
Pumpkin & Yes & Good & No, but has interest & Comparable to conventional \\
Watermelon & Yes & Good with strip-till & No, but has interest & Comparable to conventional with strip till \\
\hline
\end{tabular}

will be delayed. D elayed harvest due to weed competition is highly undesirable for most cabbage growers who sell on the fresh market. A 5-d delay can negatively affect the profitability of a spring cabbage crop and will reduce the interest of growersin pursuing CT methods.

StraWberRies. Plasticulture strawberry (Fragaria xananassa Duchesne) growers who use slightly sloping land arealso implementing CT practices. After the plastic is laid in the fall, they are seeding a cover crop, usually annual ryegrass (Lolium multiflorum Lam.), oats (A vena sativa L.) or other small grains, between the plastic beds. This practice is proving to be of major benefit. Water from winter rainsruns off the plastic and collects between the rows. Without the cover crop on this rolling terrain, soil erosion can become severe. With the presence of a cover crop between the plastic beds, winter soil erosion is reduced considerably in many of the fields. Sufficient growth of the cover crop may al so reduce winter damage to the strawberry crowns by reducing temperature fluctuations and extremes.

Growers are killing the cover crop in the spring with sethoxydim. In addition to preventing soil erosion, the cover crop residue then serves as a mulch to enablebetter harvesting conditionsduring wet weather as well as keeping the fruit cleaner.

\section{Status in Tennessee}

Successful CT in row-crop production has created some interest in $\mathrm{CT}$ among vegetablegrowers. Even though there have been some successful onfarm demonstrations with vegetables, the present interest in adopting the practice is still low. Table 4 provides a good interpretative summary of the overall situation with respect to $\mathrm{CT}$ of vegetable crops in Tennessee.

\section{Conclusions}

Conservation tillage of vegetable crops has not been raised to a level equival ent to conventional tillage. $\mathrm{H}$ owever, the potential for making it a viable production practice is becoming more promising with certain vegetable crops in Tennessee. Sufficient grower interest hasoccurred with tomatoes, sweet corn, cabbage, pumpkins and strip-till watermelons to indicate that CT may be practical. Snap bean production results have been variable, but $C T$ appears increasingly feasible as research continues to refine cultural practices. Energy savings in land preparation, reduced soil erosion on sloping terrain, harvesting of a higher percentage of clean fruit, improved ease in making spray applications and feasibilityof harvest during wet weather areall positive aspects of $\mathrm{CT}$. Conservation tillage practices are preferred by those who advocate reduction of production impacts on the environment.

There are certain problems with CT of vegetable crops. Weed management with CT is often a problem. Cover crop residuecan result in reduced product quality of certain processing crops that have fruit close to the ground surface, when harvest machinespick up this residue. Placement of fertilizer and lime into the root zone ismore difficult with $\mathrm{CT}$ and requires equipment modification. In some cases, modification at the site is necessary. Soil conditions greatly affect seed coverage and soil to root ball contact. With vertically growing crops that require mechanical support, soil conditions may even affect the staking process. $M$ anagement of the cover crop is also very important in successful production.

Progress has been made in developing CT production practices feasible with commercial vegetable crops in Tennessee. The interest in producing vegetablesusing $C T$ islikely to continue as more and more of the less erodible land is removed from agricultural production. Continued loss of desirable farm land will require further emphasis on CT methods in all segments of agriculture.

\section{Literature cited}

Bradley, J.F. and D.D. Tyler. 1996. Notill: Sparing the plow to save the soil. Tenn. Agr. Sci. 179:7-10.

G raves, C.R. 1996. Progress of no-till soybean production in Tennessee. Tenn. Agr. Sci. 179:28-31.

H oward, D .D ., M .E. Essington, and G .M . Lessman. 1996. Fertilizer information for no-till systems. Tenn. Agr. Sci. 179:3840.

Kelly, W.T. 1993. Agronomic and allelopathic effects of sequential cropping and tillage on tobacco and vegetable production. PhD diss. U niv. Tenn., Knoxville.

Kreuger, W.A., K.B. Kirksey, G.N. R hodes, J r., and P.P. H unter. 1995. Weed control in no-till burley tobacco. Proc. S. Weed Sci. Soc. 48:54 (abstr.).

Morse, R. 1998. Keys to successful production of transplanted crops in high residue, no-till farming systems. 21st Annu. S. Conserv. Tillage Conf. Sustainable Agr., Ark. Agr. Expt. Sta. Spec. Rpt. 186.

M ueller, T.C. and R.M. H ayes. 1996. N otill farming and weed control. Tenn. Agr. Sci. 179:33-36.

Rutledge, A. 1997. Commercial tomato production. U niv. Tenn. Agr. Ext. Serv. PB 737.

Rutledge, A. 1996. Commercial bush snap bean production. U niv. Tenn. Agr. Ext. Serv. PB 897.

Rutledge, A. 1998. T ennessee watermelon production. U niv. Tenn. Agr. Ext. Serv. PB 1289.

Straw, R.A., C.A. M ullins, and D .L. C offey. 1995. Tillage treatments and nitrogen fertilization rates for fresh market tomatoes. Tenn. Res. Rpt. 95-08.

Straw, R.A., C.A. M ullins, and D .L. C offey. 1993. Potential of no-till tomato production in Tennessee. H ortScience 28(5):552 (abstr.).

T yler, D .D ., M .D . M ullen, and B.N . D uck. 1994. Soil management research in Tennessee. Tenn. Farm H ome Sci. 172:1013. 